\title{
Modern Methods of Training Foreign Language Teachers
}

\author{
Valentyna V. Chernysh ${ }^{1}$, Yuliia Vaseiko², Vasily Kaplinskiy ${ }^{3}$, Liudmyla Tkachenko ${ }^{4}$ \& Julia Bereziuk ${ }^{5}$ \\ ${ }^{1}$ Department of Foreign Languages Methodology Teaching and Information and Communication Technologies, \\ Faculty of Roman Philology and Translation, Kyiv National Linguistic University, Kyiv, Ukraine \\ ${ }^{2}$ Department of the Slavic Philology, Faculty of Philology and Journalism, Lesya Ukrainka Eastern European \\ National University, Lutsk, Ukraine \\ ${ }^{3}$ Department of Pedagogy and Vocational Education, Vinnytsia State Pedagogical University named after Mykhailo \\ Kotsyubynsky, Vinnytsia, Ukraine \\ ${ }^{4}$ Department of Foreign Languages, Faculty of Humanities, Cherkasy State Technological University, Cherkasy, \\ Ukraine \\ ${ }^{5}$ Natural Sciences and Humanities Department, Zhytomyr Medical Institute, Zhytomyr, Ukraine \\ Correspondence: Valentyna V. Chernysh, Kyiv National Linguistic University, 73 Velyka Vasyl'kivska str., Kyiv, \\ 03680, Ukraine.
}

Received: June 10, 2020

Accepted: August 3, 2020

Online Published: August 10, 2020

doi:10.5430/ijhe.v9n7p332

URL: https://doi.org/10.5430/ijhe.v9n7p332

\begin{abstract}
Transformational trends of the modern social and political-economic space determine the modernization of the educational sphere, in particular, the system and methods of teaching highly skilled foreign language teachers. Deficiencies in existing technologies for development professional skills, the lack of innovative, modernized techniques for training competitive teachers, as well as the need to improve the quality of teaching staff in some European countries require adjustment of methodological support for training of narrow-focused teachers; forasmuch as professional development and the competence level of teachers directly affect the formation of socially-oriented, multifunctional educational systems in different countries of the world and determines the relevance of the issues proposed for the investigation. The purpose of writing an academic paper is to analyze modern methods of organizing the educational process of foreign language teachers and determining the basic factors that have a decisive influence on the level of pedagogical competence. The following research methods have been used during the writing of the research article, namely: comparison, system-structural research, statistical-analytical, tabular, graphical methods, analytical modeling, as well as methods of abstraction, analysis and generalization. As a result of generalization of modern teaching methods in European countries, it has been determined that general education practice involves the use of formal, non-formal and informal methods of training foreign language teachers. The non-formal and informal methods are the most effective of them, forasmuch as they are connected with the high level of the educational process's coherence, professional activities and the practical aspect of applying the acquired knowledge. The practice of using non-formal technologies to improve pedagogical competence and qualification of foreign language teachers has become widely used in most European countries. A thorough analysis of non-formal education in Europe has determined that the most accessible is a multi-sensory approach to training that takes into account various aspects of language education and does not require significant financial support.
\end{abstract}

Keywords: pedagogical competence, foreign language teacher, system of professional development, advanced training, methods of professional training, self-development, educator

\section{Introduction}

Within the European-wide space, the role of quality education, in particular in the language field, is crucial, as a foreign language is a basic tool for communication processes, and the existence of the modern phenomenon of multilingualism is a key factor in enhancing interstate integration. However, the creation of a multilingual space is possible under the condition of high professional competence of foreign language teachers and the application of updated teaching methods for both teachers and students.

In modern conditions an urgent need arises to improve the methodological support for training and retraining of foreign language teachers. Some modern re-searchers insist that methods based on traditional approaches are 
effective, in particular, through the use of formal tools (obtaining education at high school). At the same time, the aspect of practical application of knowledge acquired during training is an integral part of the traditional educational model, continuous practice ensures the development of research potential of the teacher and contributes to the sustainable improvement of language skills (Gregson, 2020; Gregson \& Kessell-Holland, 2020). Besides, it should be noted that supporters of the traditional approach to training foreign language teachers emphasize the effectiveness of the use of reflective techniques, which are a means of improving speaking and writing skills (Gregson et al., 2020). Researchers claim that only the cognitive aspect has a high value in the educational process and is a determining factor in improving pedagogical competence (Hyland, 2019). However, the modern educational environment is characterized by the dynamism of development and transformation of approaches to training foreign language teachers. New, innovative and improved methods, in accordance with the requirements of current educational space, appear in contrast to traditional methods. On the basis of "innovative pedagogy" (Kukulska-Hulme et al., 2020), within the conditions of a modern highly developed technological environment, a change in the theory and practice of teaching, preparation and assessment is carried out. High efficiency of this method of organizing the educational process is ensured through compliance with the principle of "blended learning" (Bayram \& Hamit, 2014).

Accordingly, traditional approaches to training foreign language teachers and the latest trends in educational processes are characterized as independent and complemented. Currently there is no single viewpoint on effective teaching methods. The education is no longer a holistic theoretical or practical category; it is a tool to achieve long-term goals (Osberg \& Biesta, 2020). Thus this academic paper is an original study of how to effectively combine different methods in the process of training foreign language teachers, ensuring the professional development and competence of teaching staff, on the one hand, and creating a highly effective, modernized educational environment in different European countries, on the other.

The importance of practical use of research results centres on further balancing the views of scientists and developing practical methods of training foreign language teachers that will be adapted to the requirements of the interstate educational environment. Forasmuch as the modern paradigm of the professional development system is based on the idea of creating optimal conditions for both educators and students, special attention should be paid to theoretical methods, models and technologies that are widely used in Europe and have a positive experience of functioning, in order to find effective methods of training foreign language teachers.

\section{Literature Review}

A detailed analysis of the issues proposed in the academic paper makes it possible to conclude that current methods of training foreign language teachers in different European countries, modern methods of training and retraining of highly skilled teachers, as well as pedagogical competence of teachers and technologies to improve it are sufficiently studied by foreign and Ukrainian scientists.

Within the modern conditions of globalization, the European educational space changes and forms new requirements to the level of professional competence of teachers. Achieving the desired result is carried out through the transformation of methods, policies and practices of teachers' activities. Therefore, Symeonidis (2018) argues that modern methods of teachers' training should be developed, taking into account the following aspects: coordinated policy at the level of individual countries and at the level of the European-wide space; the application of intersectoral instruments of influence on educational processes - attracting financial resources from different sectors of the economy, attracting practitioners to educational activities, etc.; the use of scientifically determined teaching management methods for foreign language teachers; adaptation and application of the requirements of the Bologna process to training foreign language teachers; expanding opportunities for foreign language teachers to participate in educational national or interstate programs; consideration and adjusting the pressure on educational processes by interested parties (in particular, state and local authorities).

The development of effective methods of training foreign language teachers is based on the concept of Life Long Learning, that is, continuous professional development. Thus, in order to maintain pedagogical competence and the level of professionalism, each foreign language teacher should apply the most acceptable methods of improving the acquired specialized knowledge, adapted to their educational activities, which is a basic component of professionalism, in general.

European pedagogical literature offers three general methods of organizing the educational process for foreign language teachers: formal learning, non-formal learning and informal learning. However, each of the above mentioned methods is not effective enough because of absence of "blended learning" principles; therefore, modern teachers of a foreign language should be able to integrate constructivist and traditional models of education in a blended learning environment, which will become the basis for the professional growth of the teaching staff (Horn \& 
Staker, 2011). According to the interpretation of UNESCO (2011), education is formal when it is institutionalized, and educational process planning is carried out at the level of state and local executive authorities. Formal education curricula are formed under the supervision of competent employees of the educational sphere, who are subordinated to national or interstate regulators. Non-formal education is also characterized by a certain level of institutionalization, however, its planning is carried out at the level of educational organizations. Non-formal education is a supplement or alternative to formal education, or it acts as a way of organizing Life Long Learning of foreign language teachers. The informal education stands out in contrast to the outlined methods, the defining characteristics of which are less structuring and organized. It is based on informal learning tools - language trainings, language learning events / meetings, seminars, etc., which are the most effective tools for improving language skills and maintaining the pedagogical competence of a foreign language teacher.

According to viewpoints of Kotenko and Holovatenko (2020), it is advisable to use binary models of training teachers for a rational combination of formal and informal methods of training foreign language teachers; its essence centers around integrating parallel and consistent methods of perception of educational material. This technology has been widely used in European countries; in particular, the Belgian educational system is characterized by positive experience in the practical application of the binary model of teaching foreign language teachers.

Supporters of traditional training methods for teachers of foreign languages insist on deepening the interconnections of practice, theory and research of a modern teacher (Spedding, Gregson \& Gregson, M., 2019). Researchers claim that the level of effective use of knowledge by teachers in practical work is formed under the direct influence of the theoretical basis and research processes in educational activities. Based on traditional teaching methods, three classical models of foreign language teachers' training have been formed, which are widely used nowadays, however, improved to the updated requirements of the modern educational environment, namely: Applied Science Model, Craft Model, Reflective Model (Wallace, 1991). Whereas Day (1991) has supplemented this list and offered such models of training foreign language teachers, as: Apprentice-Expert Model; Rationalist Model, Case Studies Model, Integrative Model.

However, formal and informal methods (Kukulska-Hulme et al., 2020) of organizing the educational process of foreign language teachers can be built on the basis of innovative and scientific and technical achievements of modern society. Modern researchers claim that among them the following have the greatest impact on the educational environment, namely:

- The use of artificial intelligence in educational methods (Holmes, Bialik \& Fadel, 2019) in order to adapt the theoretical knowledge of teachers to modernized and computerized life;

- Posthumanist trends, which are reflected in the simultaneous confrontation and interdependence of the teacher and the cutting-edge technologies (Bayne, 2018);

- Training foreign language teachers through open databases and electronic resources, which simplifies the mechanism of using real information data for personal self-development and professional enhancement (Coughlan, 2019; Zimmer, 2010); the application of open databases helps both foreign language teachers and their students understand and select the most appropriate sources of information, as well as process, analyze and interpret the acquired knowledge (Atenas, Havermann \& Priego, 2015);

- Modern pedagogical ethics (Cameron \& O'Leary, 2015) and social justice (Belle, 2019) in the educational process. The trends outlined are typical of informal methods of training foreign language teachers, as they are based on the principles of cooperation and tolerance in the field of education, providing the observance of ethical behavior of each party of the educational process (Cumming-Potvin, 2009);

- The use of multisensory teaching methods in training foreign language teachers, which increases the efficiency of information perception and attracts people with special needs to professional development (Van Staden \& Purcell, 2016).

Taking into consideration the current trends of social interaction's complexity, non-formal and informal distance learning methods for training foreign language teachers are of great relevance. Under modern circumstances, pedagogy changes its format, the gradual introduction of electronic information affects both the national educational space and the everyday life of individual subjects of educational relations: the aim of a modern educator centers around achieving an ideal balance between family relationships and learning interrelation, which is quite a complex, ontological challenge for educators (Peters et al, 2020).

Statistical and analytical information on the effectiveness of modern methods of training and retraining foreign language teachers, the current basic trends in education and the effectiveness of combining different approaches in 
the context of improving the pedagogical competence of educators have been systematized and summarized in statistical and analytical collected papers of European Commission (2019).

\section{Methods and Materials}

The basic research methods used in the article are as follows: comparison, system-structural research, statistical-analytical, tabular, graphical methods, analytical modelling, as well as methods of abstraction, analysis and generalization.

Methods of comparison, analysis and generalization have been used to study the theoretical and methodological basis of educational processes in European countries and modern methods of training highly skilled foreign language teachers, which made it possible to distinguish between various aspects of the organization of European educational environment.

The following indicators have been used to conduct an analysis:

1. The level of involvement of educators in formal education in terms of different age categories (2007, 2011, 2016, \%).

2. The level of involvement of educators in non-formal education in terms of different age categories (2007, 2011, 2016, \%).

3. The level of involvement of foreign language teachers in formal, non-formal or informal learning in 2019 (\%).

4. The level of involvement of teachers in non-formal education in terms of different technologies of information presentation, $2019(\%)$.

5. The level of learning different foreign languages by students in European countries (2018, \%).

6. Dynamics of the share of students who studied English, German, French or Spanish during 2014-2018 (\%).

Based on the indicators specified, trends in the training foreign language teachers within EU have been identified and differences regarding training models and teaching methods have been revealed. The indicators outlined determine the trends in teachers' training.

A schematic method has been used to identify the connection in training methods, as well as the system of methods of training foreign language teachers has been constructed. The system of methods includes both formal and non-formal education. Such approach comprehensively reflects the latest trends in training foreign language teachers.

Thus, these methods have been applied in order to identify the characteristic features of current methods of training foreign language teachers and to investigate the key features of modern technologies for teaching staff, preparing within the conditions of transformation of educational processes and high mobility of foreign language teachers. The method of system-structural research has been applied to outline the conceptual foundations and principles of using different methods of teachers' training depending on the level of educational processes in individual European countries. Statistical-analytical method has been used in the process of analyzing the state and dynamics of the educational environment in European-wide practice. At the same time, due to the use of tabular, graphical and analytical modelling, an analysis of the level of involvement of foreign language teachers in formal, non-formal or informal learning has been conducted, as well as the level of use of multisensory methods of training foreign language teachers in the context of individual European countries.

\section{Results of the Research}

Currently European countries are actively using various methods of training foreign language teachers. Although modern international practice of teachers' training is characterized by the integration of different technologies, approaches and techniques, the European-wide educational environment can be characterized as a single educational space, which has the features of integrity, structure, multiplicity and interdependence of individual components of the educational sphere, in particular, economic, ideological, informational, social-cultural, scientific-methodological and research elements. Generalization of practical methods of training foreign language teachers, which are widely used in modern educational systems of European countries is reflected in Figure 1.

Differentiation of formal, non-formal and informal training of foreign language teachers in European countries aims to maximize the positive effect of each of these methods, while minimizing the shortcomings of the outlined approaches. Thus, due to formal training methods, foreign language teachers have the opportunity to obtain an official degree and document their pedagogical competence and professional qualifications, which is not possible within the conditions of non-formal training methods. 
The level of involvement of educators in formal and non-formal education in the dynamics is reflected in Table 1 and Table 2, respectively.

Analytical data on the participation of educators in formal education indicate a rather low level: the highest indicator is typical for the age category of educators from 25 to 34 years (in $2007-13,3 \%$ ), the lowest - for the category from 55 to 64 years (in $2016-0,9 \%$ ). The main reason for such trends is the high standardization of the educational process, which limits opportunities for self-development and self-organization. The insufficient level of investment in formal education is equally important, which reduces its technological effectiveness and innovativeness.

A high degree of institutionalization of the educational environment provides the organization and structuring of educational processes, the presence of interaction of teaching staff with educational organizations. The principle of institutionalization is implemented through the definition of certain standards of education: training method, curriculum, schedule and place of study (specially created educational organizations). Non-formal education has a simplified mechanism of foreign language teachers' activities, thanks to which the specialists get the opportunity to organize their educational process in accordance with their own interests and capabilities.

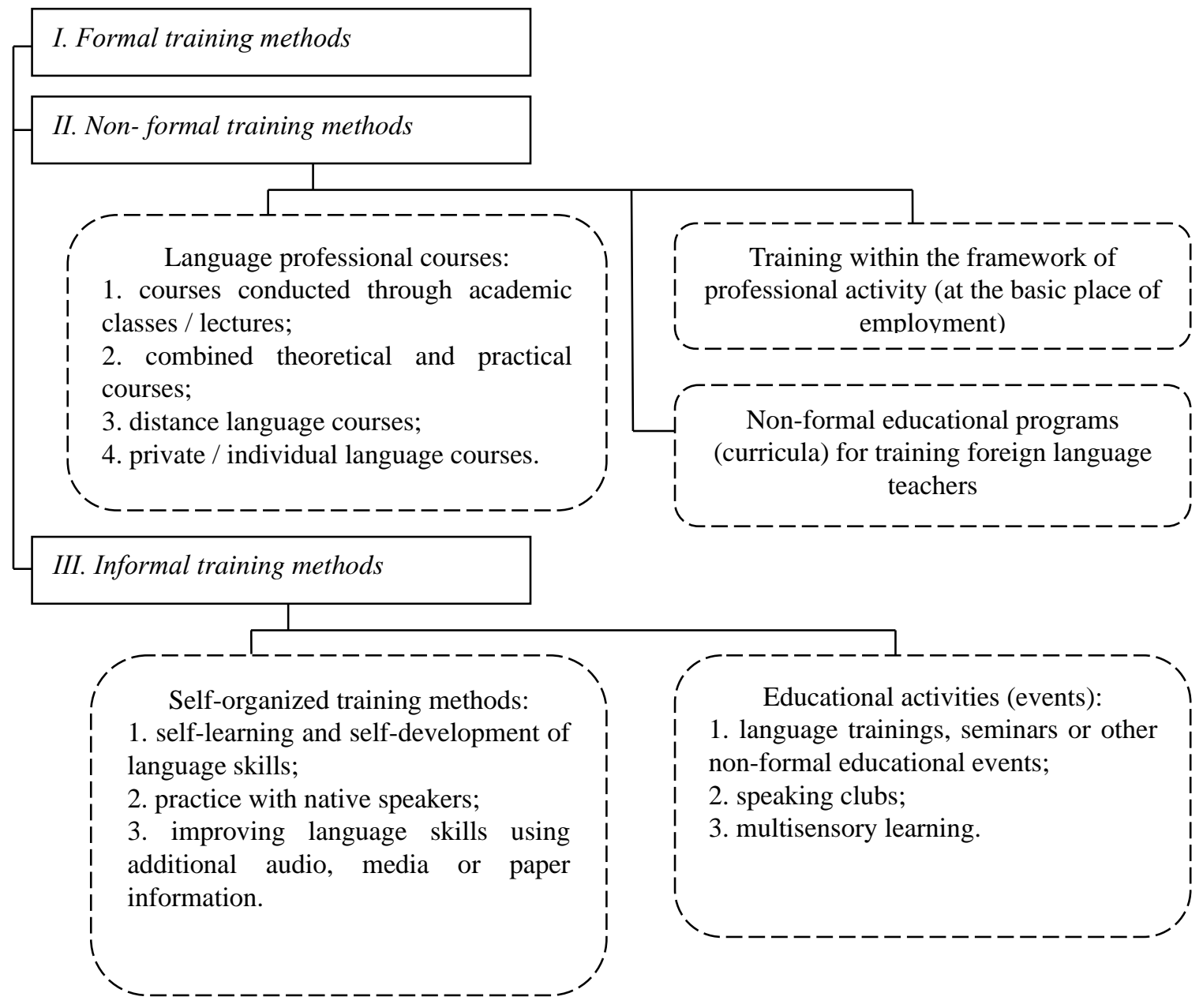

Figure 1. Modern methods of training foreign language teachers (Eurostat, 2016) 
Table 1. The level of involvement of educators in formal education in terms of different age categories (2007, 2011, 2016, \%) (Eurostat, 2020)

\begin{tabular}{|c|c|c|c|c|c|c|c|c|c|}
\hline \multirow{3}{*}{ Country } & \multicolumn{9}{|c|}{ Formal education and training } \\
\hline & \multicolumn{3}{|c|}{ from 25 to 34 years } & \multicolumn{3}{|c|}{ from 35 to 54 years } & \multicolumn{3}{|c|}{ from 55 to 64 years } \\
\hline & 2007 & 2011 & 2016 & 2007 & 2011 & 2016 & 2007 & 2011 & 2016 \\
\hline Austria & 11,4 & 13,1 & 16,6 & 2,4 & 4,3 & 3,9 & - & 1,9 & - \\
\hline Belgium & 21,8 & 12,9 & 15,2 & 11,2 & 6,7 & 5,0 & 7,4 & 3,6 & 2,5 \\
\hline Bulgaria & 7,4 & 7,4 & 7,6 & 1,5 & 1,0 & 1,9 & - & - & - \\
\hline Croatia & 13,1 & - & 11,4 & 2,2 & - & 2,8 & - & - & - \\
\hline The Czech Rep. & 9,8 & 9,2 & 7,6 & 2,6 & 2,3 & 1,2 & - & - & - \\
\hline Denmark & 28,0 & 30,6 & 31,9 & 7,0 & 9,6 & 9,7 & - & 3,1 & 4,1 \\
\hline Cyprus & 7,8 & 9,1 & 6,7 & 1,2 & 2,0 & 1,9 & - & - & - \\
\hline Estonia & 11,3 & 18,1 & 14,4 & 3,5 & 3,3 & 4,2 & - & - & - \\
\hline Finland & 24,0 & 26,9 & 32,4 & 8,5 & 9,9 & 11,1 & - & 2,4 & - \\
\hline France & 11,7 & 8,8 & 7,8 & 3,5 & 2,6 & 2,7 & 0,8 & 0,5 & 0,5 \\
\hline Hungary & 7,2 & 13,1 & 14,7 & 1,5 & 5,9 & 6,6 & - & 0,9 & 2,2 \\
\hline Greece & 5,8 & 8,1 & 10,9 & 1,4 & 1,2 & 2,2 & - & - & - \\
\hline Ireland & - & 11,2 & 14,8 & - & 5,6 & 7,9 & - & 2,3 & 2,8 \\
\hline Latvia & 10,8 & 8,9 & 11,5 & 4,7 & 3,4 & 2,8 & - & - & - \\
\hline Lithuania & 16,4 & 11,9 & 7,5 & 3,5 & 1,7 & - & - & - & - \\
\hline Luxembourg & - & 17,8 & 18,0 & - & 7,9 & 6,0 & - & 5,7 & 3,3 \\
\hline Malta & 10,0 & 8,1 & 14,7 & 4,9 & 4,4 & 5,2 & - & - & - \\
\hline The Netherlands & 15,2 & 21,4 & 20,2 & 5,1 & 11,4 & 7,0 & 2,4 & 4,5 & 2,5 \\
\hline Norway & 20,8 & 14,2 & 26,5 & 8,2 & 7,3 & 8,2 & - & - & 4,9 \\
\hline Poland & 13,4 & 12,7 & 10,8 & 3,2 & 3,5 & 2,9 & - & - & - \\
\hline Portugal & 13,9 & 17,4 & 11,9 & 4,8 & 10,3 & 2,5 & 1,2 & 3,0 & 0,7 \\
\hline Romania & 8,7 & 3,4 & 4,9 & 2,4 & 0,9 & 0,9 & - & - & - \\
\hline Slovakia & 12,7 & 12,0 & 4,2 & 4,5 & 4,5 & - & - & - & - \\
\hline Slovenia & 22,3 & 7,2 & 16,2 & 5,5 & 0,9 & 4,4 & - & - & - \\
\hline Spain & 11,8 & 14,3 & 22,3 & 4,1 & 5,2 & 8,2 & 1,8 & 2,1 & 2,5 \\
\hline Sweden & 26,5 & 28,3 & 28,6 & 11,4 & 11,2 & 11,3 & 2,7 & 3,4 & 2,7 \\
\hline Switzerland & 12,1 & 22,9 & 21,7 & 3,5 & 6,1 & 5,5 & 0,7 & 1,2 & 1,4 \\
\hline The UK & 23,1 & 22,6 & 17,4 & 14,7 & 14,9 & 12,0 & 7,7 & 6,1 & 5,1 \\
\hline Turkey & 5,5 & 9,5 & 11,6 & 0,8 & 2,0 & 2,9 & - & - & - \\
\hline Serbia & - & 12,5 & 9,8 & - & 1,5 & 1,3 & - & - & - \\
\hline Total average & 13,3 & 12,4 & 13,0 & 3,6 & 3,6 & 3,5 & 1,2 & 1,0 & 0,9 \\
\hline
\end{tabular}


Table 2. The level of involvement of educators in non-formal education in terms of different age categories (2007, 2011, 2016, \%) (Eurostat, 2020)

\begin{tabular}{|c|c|c|c|c|c|c|c|c|c|}
\hline \multirow{3}{*}{ Country } & \multicolumn{9}{|c|}{ Non-formal education and training } \\
\hline & \multicolumn{3}{|c|}{ from 25 to 34 years } & \multicolumn{3}{|c|}{ from 35 to 54 years } & \multicolumn{3}{|c|}{ from 55 to 64 years } \\
\hline & 2007 & 2011 & 2016 & 2007 & 2011 & 2016 & 2007 & 2011 & 2016 \\
\hline Austria & 40,2 & 49,3 & 65,4 & 44,9 & 47,9 & 62,7 & 25,2 & 35,2 & 41,3 \\
\hline Belgium & 44,4 & 41,3 & 51,0 & 35,9 & 36,5 & 43,9 & 19,1 & 17,4 & 27,5 \\
\hline Bulgaria & 41,2 & 25,8 & 23,6 & 39,2 & 28,6 & 25,7 & 23,3 & 15,0 & 14,6 \\
\hline Croatia & 24,7 & - & 37,7 & 19,1 & - & 34,1 & 9,0 & - & 15,5 \\
\hline The Czech Rep. & 38,0 & 38,8 & 47,0 & 41,8 & 39,9 & 49,7 & 21,5 & 20,1 & 29,1 \\
\hline Denmark & 35,7 & 52,2 & 43,9 & 43,4 & 56,6 & 48,0 & 27,3 & 44,7 & 35,1 \\
\hline Cyprus & 50,0 & 46,3 & 56,0 & 40,9 & 43,0 & 49,4 & 20,0 & 27,7 & 29,8 \\
\hline Estonia & 48,0 & 59,2 & 46,2 & 41,5 & 58,9 & 43,8 & 27,2 & 32,6 & 30,0 \\
\hline Finland & 55,7 & 54,8 & 53,3 & 55,9 & 58,6 & 51,7 & 37,1 & 34,7 & 33,8 \\
\hline France & 41,1 & 57,5 & 58,0 & 33,8 & 53,0 & 53,5 & 15,9 & 32,7 & 34,9 \\
\hline Hungary & 9,7 & 44,3 & 56,6 & 4,7 & 42,3 & 57,9 & 2,5 & 21,2 & 37,2 \\
\hline Greece & 18,5 & 13,7 & 21,3 & 12,8 & 10,3 & 14,7 & 5,1 & 3,1 & 5,6 \\
\hline Ireland & - & 19,4 & 56,4 & - & 20,0 & 50,8 & - & 14,3 & 38,7 \\
\hline Latvia & 35,2 & 33,1 & 51,7 & 32,5 & 32,9 & 48,6 & 20,9 & 19,1 & 34,0 \\
\hline Lithuania & 33,6 & 29,0 & 31,6 & 34,0 & 28,3 & 27,8 & 18,9 & 16,1 & 19,1 \\
\hline Luxembourg & - & 75,7 & 51,2 & - & 71,4 & 48,4 & - & 48,5 & 29,4 \\
\hline Malta & 45,6 & 40,9 & 44,2 & 32,4 & 38,9 & 35,1 & 15,5 & 19,7 & 18,8 \\
\hline The Netherlands & 52,5 & 62,8 & 67,7 & 43,7 & 58,9 & 63,6 & 28,2 & 35,7 & 51,2 \\
\hline Norway & 56,0 & 65,4 & 56,0 & 52,6 & 60,4 & 58,5 & 40,3 & 40,0 & 45,4 \\
\hline Poland & 26,0 & 28,1 & 27,3 & 18,9 & 22,6 & 25,6 & 6,7 & 9,4 & 13,3 \\
\hline Portugal & 31,8 & 53,2 & 55,4 & 22,6 & 41,6 & 47,4 & 10,2 & 20,0 & 28,3 \\
\hline Romania & 6,7 & 10,1 & 9,8 & 4,8 & 7,2 & 5,5 & 2,5 & 1,9 & 1,5 \\
\hline Slovakia & 44,6 & 42,7 & 51,0 & 46,5 & 43,1 & 48,7 & 23,8 & 21,6 & 30,3 \\
\hline Slovenia & 40,0 & 38,6 & 48,7 & 40,2 & 39,0 & 49,6 & 22,0 & 22,7 & 27,3 \\
\hline Spain & 32,5 & 40,5 & 44,9 & 28,3 & 35,4 & 41,3 & 15,7 & 22,0 & 28,0 \\
\hline Sweden & 72,4 & 67,0 & 54,1 & 72,8 & 71,6 & 59,0 & 60,1 & 57,1 & 53,5 \\
\hline Switzerland & 49,8 & 65,7 & 75,7 & 49,8 & 65,6 & 68,3 & 36,6 & 53,8 & 57,1 \\
\hline The UK & 44,3 & 23,9 & 54,3 & 41,8 & 25,4 & 48,8 & 32,5 & 22,3 & 36,6 \\
\hline Turkey & 18,0 & 20,8 & 24,0 & 11,6 & 14,4 & 18,0 & 4,4 & 5,4 & 6,4 \\
\hline Serbia & - & 18,3 & 23,7 & - & 15,1 & 21,5 & - & 5,8 & 7,3 \\
\hline Total average & 35,5 & 42,9 & 56,5 & 33,0 & 41,6 & 44,8 & 18,2 & 26,0 & 31,9 \\
\hline
\end{tabular}

In turn non-formal education leads to obtaining high qualifications that are not officially recognized or equivalent to those that can be obtained in the process of traditional training, although, the practice of combining formal and non-formal education shows a greater effectiveness of non-formal teachers' training technologies. Non-formal education is less structured, which makes it quite dependent on innovative and scientific-technical activities. Accordingly, in the context of studying effective modern methods of training or retraining foreign language teachers, emphasis should be placed on non-formal education, which ensures a high level of professionalism of today's teaching staff. 
Thus, the data indicate the priority of non-formal and informal training methods of foreign language teachers, increasing the share of non-formal technologies for training is connected with deepening cooperation in the field of interstate educational processes, innovation and modernization of today's society. European policy in the field of education is aimed at supporting the sustainable development of teacher's competence, which is reflected not only in the form of theoretical knowledge. First of all, the pedagogical competence of a foreign language teachers centers around rational using of their skills, as well as the ability to deliver them to students or pupils. According to the Rome Declaration of the Council of the European Union (2017), 27 European countries have committed themselves to the principle of Life Long Learning in the structure of national educational systems. Currently, the competence of foreign language teachers occupies a leading position in the structure of educational systems in some European countries, taking into consideration the priority of applied linguistics, which is caused by the transformation of society, globalization and mobility of labor resources. Thus, training focused on high qualifications and professional development is more important, as practical skills are more valuable in the context of multi-vector, social-economic and educational processes.

The defining aspects and advantages of modern informal methods of teachers' training can be described as follows:

1. Acquiring of new knowledge on the basis of practice and direct teaching of foreign languages;

2. The opportunity to gain experience through participation in various research projects or educational programs;

3. The possibility of implementing language projects within the European educational space.

However, the general state of involvement of teachers in education, professional development, retraining or advanced training is satisfactory, as evidenced by the indicators as of 2019. Formal and non-formal education are becoming more balanced, and, therefore, receive new opportunities for development. The trends specified confirm that postgraduate educational systems in Europe are effective and promising. The state of involvement of foreign language teachers in vocational training with the use of combined methods is reflected in Figure 2 (the analysis covers all age groups - from 25 to 64 years old).

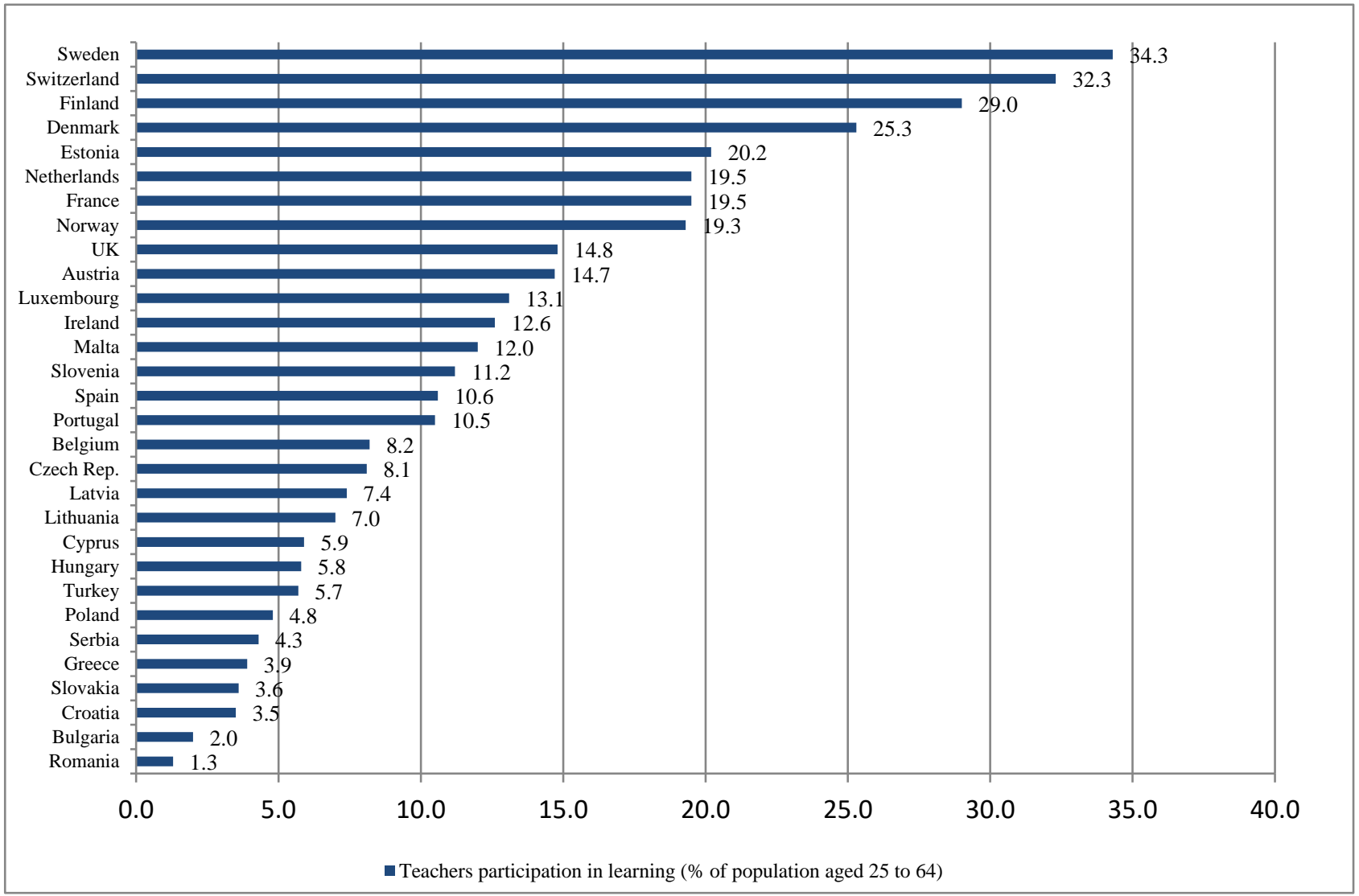

Figure 2. The level of involvement of foreign language teachers in formal, non-formal or informal learning in 2019(\%) (Eurostat, 2020) 
It should be noted that the organization of the European system of education contributes to the increase of pedagogical competence and professional development of foreign language teachers. The aspect of the European space provides for mutually agreed cooperation of educational institutions of individual countries. The basic purpose of such cooperation is the exchange of relevant information and the cutting-edge learning strategies.

The multi-sensory methods should be noted as one of the most widely used in-formal methods of training foreign language teachers; its essence centers around involving various organs of perception and analysis of information. The effectiveness of multisensory technology towards increasing the pedagogical competence of foreign language teachers has been proven in most European countries, as evidenced by the data in Table 3.

Table 3. The level of involvement of teachers in non-formal learning in terms of different technologies of information presentation, $2019(\%)$ (Eurostat, 2020)

\begin{tabular}{|c|c|c|c|c|}
\hline Country & $\begin{array}{l}\text { By using } \\
\text { printed } \\
\text { material }\end{array}$ & $\begin{array}{l}\text { By using } \\
\text { computers }\end{array}$ & $\begin{array}{l}\text { Through television/ } \\
\text { radio/video }\end{array}$ & $\begin{array}{c}\text { By visiting learning } \\
\text { centres (including } \\
\text { libraries) }\end{array}$ \\
\hline Austria & 58,0 & 56,9 & 33,1 & 13,3 \\
\hline Belgium & 35,7 & 47,7 & 25,2 & 12,9 \\
\hline Bulgaria & 27,7 & 35,7 & 33,3 & 6,0 \\
\hline Croatia & 45,5 & 60,3 & 51,3 & 3,5 \\
\hline The Czech Rep. & 46,6 & 51,5 & 20,3 & 12,6 \\
\hline Denmark & 45,7 & 54,1 & 32,4 & 17,5 \\
\hline Cyprus & 48,5 & 73,6 & 33,3 & 10,5 \\
\hline Estonia & 53,3 & 66,5 & 34,8 & 18,0 \\
\hline Finland & 53,0 & 59,0 & 23,3 & 24,6 \\
\hline France & 36,5 & 57,8 & 34,2 & 9,8 \\
\hline Hungary & 29,8 & 35,7 & 26,0 & 5,7 \\
\hline Greece & 26,4 & 35,4 & 14,2 & 6,0 \\
\hline Ireland & 33,4 & 51,0 & 21,5 & 11,6 \\
\hline Latvia & 52,4 & 65,0 & 41,8 & 16,6 \\
\hline Lithuania & 11,1 & 19,5 & 5,0 & 2,2 \\
\hline Luxembourg & 48,7 & 51,9 & 29,2 & 11,1 \\
\hline Malta & 14,0 & 22,9 & 11,6 & 8,3 \\
\hline The Netherlands & 39,6 & 49,6 & 29,3 & 22,8 \\
\hline Norway & 55,7 & 73,5 & 51,0 & 21,1 \\
\hline Poland & 24,8 & 26,2 & 12,0 & 8,7 \\
\hline Portugal & 50,8 & 66,8 & 51,3 & 12,0 \\
\hline Romania & 34,4 & 37,2 & 39,5 & 5,6 \\
\hline Slovakia & 56,9 & 54,3 & 41,4 & 14,1 \\
\hline Slovenia & 37,9 & 52,1 & 26,8 & 7,3 \\
\hline Spain & 35,0 & 46,3 & 13,6 & 11,4 \\
\hline Sweden & 53,7 & 60,7 & 33,8 & 22,0 \\
\hline Switzerland & 33,3 & 34,6 & 12,3 & 7,2 \\
\hline The UK & 38,3 & 53,6 & 27,4 & 16,4 \\
\hline Turkey & 15,6 & 20,4 & 20,2 & 3,2 \\
\hline Serbia & 57,6 & 65,8 & 61,2 & 25,0 \\
\hline Total average & 36,6 & 44,1 & 26,5 & 10,3 \\
\hline
\end{tabular}

The most widely used and convenient methods of obtaining information for modern teachers are based on the use of electronic and paper media. Accordingly, the most effective digestion of educational material is carried out due to the 
visual organs of perception. Modern methods of training foreign language teachers are based mainly on self-development and self-motivation, and, therefore, the activity of implementation of multisensory technology of modern teacher's training depends solely on the level of interest of the teacher in acquiring new skills.

The use of different languages in communication is an important component of the social-cultural life of today's Europe. Therefore, further research should be conducted in the context of the priority of foreign languages in modern society. The linguistic landscape of Europe has been shaped over many years, leading to the existence and interaction of more than 60 different languages in the daily life of modern European society. Language skills play a crucial role in shaping the interstate educational space; high standards of formal education and students' ambitions to learn foreign languages are driven by a desire to expand their learning or employment opportunities in different EU member states. In the context of pedagogical competence's development, the mobility of labor resources helps reduce the shortage of highly qualified personnel, faced by some countries of the world, and proportionally distribute the labor potential of foreign language teachers. The governments of individual European countries actively support the initiative to study foreign languages and contribute to this process through political and social-economic leverage: investing in vocational education and stimulating the development of foreign language teachers are strategic priorities for the coming years (Council of the European Union, 2019).

In order to determine the most promising areas of teachers' training, it is necessary to analyze the level of learning different foreign languages by students at educational institutions. Relevant information indicators are reflected in Table 4.

Table 4. The level of learning different foreign languages by students in European countries (2018, \%). (Eurostat, 2016, 2020)

\begin{tabular}{ccccc}
\hline Country & English & German & French & Spanish \\
\hline Austria & 98,6 & 0,1 & 8,8 & 5,8 \\
Belgium & 64,4 & 5,4 & 51,5 & 0,3 \\
Bulgaria & 83,7 & 20,9 & 5,1 & 1,4 \\
Croatia & 88,0 & 22,7 & 3,2 & 0,5 \\
Czech Rep. & 90,1 & 29,2 & 0,9 & 2,1 \\
Denmark & 15,2 & 0,6 & 0,8 & 0,1 \\
Cyprus & 98,8 & 1,1 & 5,8 & 0,1 \\
Estonia & 31,0 & 1,0 & 0,1 & 0,1 \\
Finland & 96,1 & 1,2 & 1,4 & 1,3 \\
France & 96,2 & 3,8 & 100,0 & 27,7 \\
Hungary & 64,7 & 28,4 & 0,4 & 0,1 \\
Greece & 67,0 & 0,1 & 1,4 & 0,1 \\
Latvia & 78,6 & 11,8 & 1,1 & 0,8 \\
Lithuania & 64,1 & 1,8 & 0,2 & 0,1 \\
Luxembourg & 61,1 & 74,0 & 80,9 & 0,3 \\
Malta & 100,0 & 0,2 & 0,4 & 0,3 \\
The Netherlands & 66,9 & 8,6 & 0,1 & 0,1 \\
Norway & 45,7 & 0,1 & 0,1 & 0,1 \\
Poland & 91,1 & 66,6 & 2,7 & 1,2 \\
Portugal & 83,0 & 0,6 & 8,7 & 4,6 \\
Romania & 98,9 & 7,5 & 88,6 & 0,5 \\
Slovakia & 90,8 & 31,2 & 1,9 & 1,0 \\
Slovenia & 94,5 & 26,6 & 0,2 & 1,2 \\
Spain & 39,6 & 0,1 & 0,1 & 2,0 \\
Sweden & 99,9 & 1,1 & 0,4 & \\
Iceland & 24,2 & 1,0 & 0,2 & \\
\hline & & & & 0,1 \\
\hline
\end{tabular}


The level of learning different foreign languages by students in European countries reflects that the teaching English, German, French and Spanish is the most promising, and, therefore, further training of teachers should focus on imps $201<$

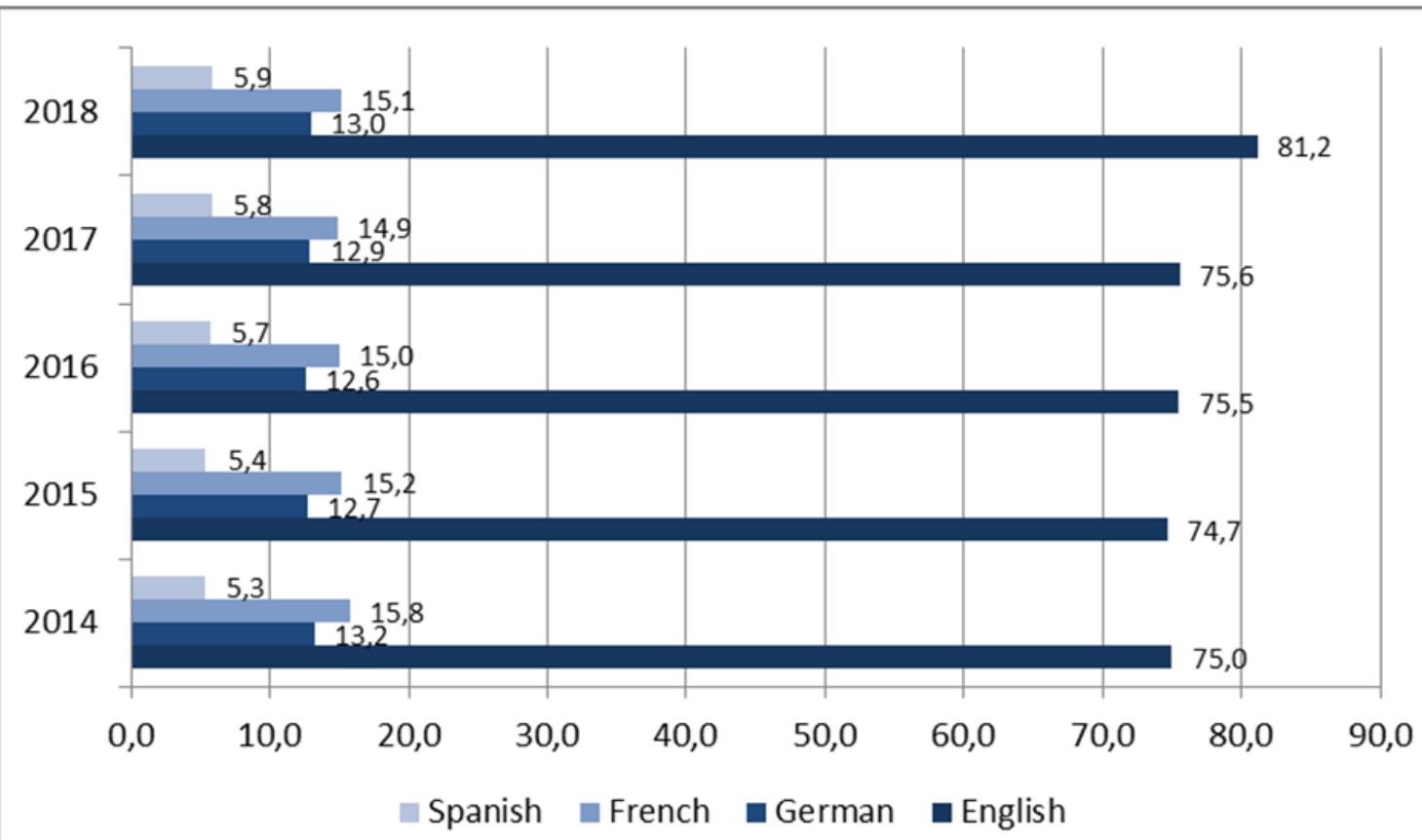

Figure 3. Dynamics of the share of students who studied English, German, French or Spanish during 2014-2018 (\%) (Eurostat, 2016, 2020).

Thus, in our opinion, the most appropriate method of training foreign language teachers is to achieve a balance between the use of proven traditional approaches and innovative tools for presenting information. In order to increase the professional competence of a modern teacher, it is important to expand the opportunities for learning different foreign languages, preserving the linguistic diversity of the European-wide educational space, introduction of the cutting-edge technologies for training of multidisciplinary specialists through the use of multilingual approaches to teachers' training or expanding the offer of bilingual courses.

\section{Discussion}

As a result of the research conducted, it has been determined that modern methods of training foreign language teachers cover a wide variety of new, modernized technologies for training highly-skilled teachers. The basic purpose of the development of professional competence of specialists is to educate the teacher's responsibility not only for the personal level of development, but also for the quality of knowledge delivered to pupils and students. A sense of responsibility is a driving factor in the structure of educational, social-economic, political and cultural progress.

In fact, the further formation of multicomponent educational systems in European countries should be carried out on the basis of personal responsibility and initiative. The following organizational aspects of education should be rationally combined in order to stimulate the learning activity of foreign language teachers, namely:

-At the macro-level - improving the financial, institutional and organizational-regulatory component of educational processes;

-At the meso-level - increase of public activity and transformation of educational organizations within a certain region;

-At the micro level - ensuring individual motivation and purposefulness of a modern foreign language teacher.

Modern researchers, in particular those mentioned before in our study, insist on the importance of practical activities in the structure of teachers' training. However, in our opinion, training should be considered as a system that has not only internal factors, shaping the level of qualification and professional competence, but also external ones that create conditions for the implementation and transfer of acquired knowledge. Today's European environment is characterized by innovativeness and technological effectiveness, and therefore further general educational transformation should take this factor into account (Kukulska-Hulme et al, 2020). 
In the process of improving modern training methods of foreign language teachers, it should be borne in mind that the political and economic basis creates both opportunities and obstacles for personal or professional development of teachers, as well as the educational system in general.

\section{Conclusions}

The obtained results are important for the development of new methods in the process training foreign language teachers. Further investigations should be aimed at improving the interaction between the three key training methods formal, non-formal and informal. The need to apply the latest approaches to the training highly-skilled personnel is caused by increasing relevance and social significance of foreign languages, language knowledge and skills in the system of the European educational space. The conducted study opens up prospects for further development of updated methods in the process of training foreign language teachers, which is a necessary condition in order to meet the full range of educational needs of modern society.

\section{References}

Atenas, J., Havermann, L., \& Priego, E. (2015). Open data as open educational resources: Towards transversal skills and global citizenship. Open Praxis, 7(4), 377-389. https://doi.org/10.5944/openpraxis.7.4.233.

Bayne, S. (2018). Posthumanism: A navigation aid for educators. Journal for Research and Debate, 2. Retrieved from https://sianbayne.net/posthumanism-a-navigation-aid-for-educators/

Bayram, G. \& Hamit, C. (2014). A proposal for a blended learning methodology and how to apply it with university students. Procedia - Social and Behavioral Science, 116, 4596-4603.

Belle, C. (2019).What is social justice education anyway? Education Week, 38(19), 18-19.

Cameron, R. A., \& O’Leary, C. (2015). Improving ethical attitudes or simply teaching ethical codes? The reality of accounting ethics education. Accounting Education, 24(4), 275-290. https://doi.org/10.1080/09639284.2015.1036893

Coughlan, T. (2019). The use of open data as a material for learning. Educational Technology Research and Development, 68, 383-411. https://doi.org/10.1007/s11423-019-09706-y

Council of the European Union. (2017). The Rome declaration. Declaration of the leaders of 27 member states and of the European Council, the European Parliament and the European Commission. Brussels, Belgium: General Secretariat of the Council.

Council of the European Union. (2019). Recommendation on a comprehensive approach to the teaching and learning of languages. Retrieved from https://eur-lex.europa.eu/legal-content/EN/TXT/PDF/?uri=CELEX:32019H0605(02)\&from=EN

Cumming-Potvin, W. (2009) Social justice, pedagogy and multiliteracies: Developing communities of practice for teacher education. Australian Journal of Teacher Education, 34(3), 82-99. https://doi.org/10.14221/ajte.2009v34n3.4

Day, R. R. (1991). Models and the Knowledge Base of Second Language Teacher Education. University of Hawai ' $i$ Working Papers in ESL, 11(2), 1-13.

European Commission. (2019). Education and Training Monitor 2019. Luxembourg: Publications Office of the European Union.

Eurostat. (2016). Classification of learning activities (CLA). Luxembourg: Publications Office of the European Union.

Eurostat. (2020). Education and training. Retrieved from https://ec.europa.eu/eurostat/web/education-and-training/data/database

Gregson, M. (2020). In Practice: The Importance of Practitioner Research in Vocational Education. Education Sciences, 10(3), 79-97. https://doi.org/10.3390/educsci10030079

Gregson, M., \& Kessell-Holland, P. (2020). Practice! Practice! Practice! In M. Gragsom \& P. Spedding, (Eds.), Practice-Focused Research in Further Adult and Vocational Education Shifting Horizons of Educational Practice, Theory and Research. London, UK: Palgrave Macmillan.

Gregson, M., Hillier, Y., Biesta, G., Duncan, S., Nixon, L., Spedding, T., \& Wakeling, P. (2020). Reflective teaching in further, adult and vocational education. London, UK: Bloomsbury. 
Holmes, W., Bialik, M., \& Fadel, C. (2019). Artificial intelligence in education: Promises and implications for teaching and learning. Boston, MA: Center for Curriculum Redesign.

Horn, M. B., \& Staker, H. (2011). The rise of K-12 Blended Learning. Technical Report Innosight Institute. Retrieved from https://www.christenseninstitute.org/wp-content/uploads/2013/04/The-rise-of-K-12-blended-learning.pdf

Hyland, T. (2019). Embodied learning in vocational education and training. Journal of Vocational Education and Training, 7l(1), 449-463. https://doi.org/10.1080/13636820.2018.1517129

Kotenko, O. V. \& Holovatenko, T. Y. (2020). Models of foreign language primary school teachers' training in EU. In N. Ababilova (Ed.), Innovative Scientific Researches: European Development Trends and Regional Aspect. Collective monograph, $1^{\text {st }}$ ed., 92-115. Riga, Latvia: Baltija Publishing. https://doi.org/10.30525/978-9934-588-38-9-5

Kukulska-Hulme, A., Beirne, E., Conole, G., Costello, E., Coughlan, T., Ferguson, R., ... Whitelock, D. (2020). Innovating Pedagogy 2020: Open University Innovation Report 8. Milton Keynes, UK: The Open University.

Osberg, D., \& Biesta, G. (2020). Beyond curriculum: Groundwork for a non-instrumental theory of education. Educational Philosophy and Theory, 52, 1-14. https://doi.org/10.1080/00131857.2020.1750362

Peters, M. A., Rizvi, F., McCulloch, G., Gibbs, P., Gorur, R., Hong, M., ... Misiaszek, L. (2020). Reimagining the new pedagogical possibilities for universities post-Covid-19. Educational Philosophy and Theory, 52. https://doi.org/10.1080/00131857.2020.1777655

Spedding, T., Gregson, D. \& Gregson, M. (2019). Top-down and outside-in: Breaking boundaries between research, theory and practice in education. Journal of Management Policy and Practice, 20(3), 36-52. https://doi.org/10.33423/jmpp.v20i3.2229

Symeonidis, V. (2018). Revisiting the European teacher education area: The transformation of teacher education policies and practices in Europe. Center for Educational Policy Studies Journal, 8(3), 13-34. https://doi.org/10.26529/cepsj.509

UNESCO. (2011) International Standard Classification of Education. ISCED 2011. Retrieved from http://uis.unesco.org/sites/default/files/documents/international-standard-classification-of-education-isced-2011en.pdf

Van Staden, A., \& Purcell, N. (2016). Multi-sensory learning strategies to support spelling development: A case study of second-language learners with auditory processing difficulties. International Journal on Language, Literature and Culture in Education, 3(1), 40-61. https://doi.org/10.1515/llce-2016-0003

Wallace, M. J. (1991). Training foreign language teachers: A reflective approach. Cambridge, UK: Cambridge University Press.

Zimmer, M. (2010). But the data is already public. Ethics and Information Technology, 12(4), 313-325. https://doi.org/10.1007/s10676-010-9227-5 